1981

\title{
Linguistic Legislation and Transnational Commercial Activity: France \& Belgium
}

Thomas E. Carbonneau

Penn State Law

Follow this and additional works at: http://elibrary.law.psu.edu/fac_works

Part of the Comparative and Foreign Law Commons

\section{Recommended Citation}

Thomas E. Carbonneau, Linguistic Legislation and Transnational Commercial Activity: France \& Belgium, 29 Am. J. Comp. L. 393 (1981).

This Article is brought to you for free and open access by the Faculty Works at Penn State Law eLibrary. It has been accepted for inclusion in Journal Articles by an authorized administrator of Penn State Law eLibrary. For more information, please contact ram6023@psu.edu. 


\section{Linguistic Legislation and Transnational Commercial Activity: France \& Belgium}

For French and francophonic people, the continued vitality of their linguistic heritage is an integral part of their sense of national identity and cultural cohesiveness. The truth of this statement has been corroborated recently by legislative enactments in France and in Belgium which prescribe and/or recommend the use of French in certain private commercial and governmental activity taking place within these countries. ${ }^{1}$ This legislation represents an attempt to provide a partial remedy to what has been perceived generally as the syntactical and lexical "contamination" of the French language resulting from the dominance of English or, more precisely, American English, in international business transactions and technological development. ${ }^{2}$

Born of a common desire to protect the "integrity of the French language," 3 the provisions of the two legislative instruments are similar in many respects: the earlier French law in fact served as a model for the Belgian decree. They raise the same issues, albeit to differing degrees; namely, the wisdom of modifying linguistic usage through legislative means; the practicality of enforcing a broad, perhaps ill-defined, mandate; and the propriety of having their substantive prescriptions interpreted and applied by the courts.

Despite this similarity, the French law presents significant differences in substance and methodology. Since it is a statute, application of the French law is more wide-ranging than that of the Belgian decree. ${ }^{4}$ Rather than merely encouraging compliance with its provisions, the French law, unlike its Belgian counterpart, pro-

Thomas E. Carbonneau is Assistant Professor, Tulane University School of Law.

1. Similar legislation has been passed in other francophonic areas, most notably in Quebec and Senegal. See Bill 101 of 1977; Decret no. 73-955 of 17 October 1973. See also Note, 10 Case West. Res. J. Int. L. 543 (1978). The provisions of the Quebec law were not included in this study since that legislation, although dealing with the use of the French language, responds to a totally different political and economic situation. [See McWhinney, infra at 413.]

2. See e.g. Spaak et al., "Proposition de Décret sur la Défense de la Langue Française," 52-1 Conseil Culturel de la Communaute Culturelle Française 1-2 (19751976).

3. See e.g. Premier Ministre Haut Comité de la Langue Française, La Loi Relative a l'Emploi de la Langue Française 9-15 (1975).

4. See text at n. 73-82 infra. 
vides for penal and other sanctions. ${ }^{5}$ Moreover, in an effort to accommodate the linguistic prescriptions with contemporary rationales for legislative action, the French law has been characterized officially as an instrument of consumer protection: an attempt to safeguard the right of French consumers and workers to receive intelligible, i.e. French language, information about the products sold and the labor relations contracted within their country. ${ }^{6}$ According to this interpretation, the quest to preserve the unique properties of the French language is but an ancillary ramification of the chief objective of the law. ${ }^{7}$ The title of the Belgian decree and the debates which preceded its enactment are more forthright statements of the intent to defend the French language against English language encroachments. ${ }^{8}$

The purpose of this article is to assess legislation which attempts to regulate the use of language by measuring the consequences of these enactments on transnational commercial matters. Since the Belgian decree relies heavily upon the precedent set by the French law and is a less drastic measure, the provisions of the French statute constitute the principal focus of this study.

\section{Historical Antecedents of the French Law}

Throughout its history, France has endeavored to preserve the character of its national language through official government action. ${ }^{9}$ Although few in number, the relevant statutes and decrees attest to an unfailing determination and continuity of purpose. Early efforts were aimed at establishing the primacy of French over Latin and local dialects. ${ }^{10}$

The first "legal" recognition of what was to become the French language came in the Ninth Century. ${ }^{11}$ At that time the clergy received its religious education in Latin; the laity however spoke a form of romanized French and as a consequence were unable to understand sermons given in Latin. In 813, the Concile of Tours ordered the clergy to preach "in the rustic romane tongue, or in the germanic tongue, so that all could understand more easily." 12 De-

5. See text at n. 46-49 infra.

6. See text at $n$. 38-44 infra.

7. See text at $38-44,72-73$ infra.

8. See text at 73-82 infra.

9. For an excellent and multi-volumed discussion of the history of the French language, see Brunot, Histoire de la Langue Française des Origines a nos Jours (1967). See also 1 Caput, La Langue Française Histoire d'une Institution 842-1715 (1972); Chaurand, Histoire de la Langue Française (1969); Cohen, Histoire d'une Langue: Le Français (3d ed. 1967).

10. See generally 1 Caput, supra $n .9$ at $15-16$; Cohen, supra $n .9$ at 239-40.

11. See 1 Caput, supra n. 9 at 16.

12. See id. at 15 (my translation). 
spite this concession to the vernacular, Latin remained the language of the cultivated, the primary medium for literary, scholarly and scientific discourse. The Church and educational institutions closely associated with it continued to promote the use of Latin in all other domains. ${ }^{13}$

Around 1400 however, the French Royal Administration began to advocate the use of French in areas that came under its responsibility, especially in legal matters where the need to be understood by the parties involved obviously was great. ${ }^{14}$ In 1510 , King Louis XII prohibited the use of Latin in criminal trials and investigations, making the regional vernacular mandatory in such proceedings. ${ }^{15}$ In 1539, in the celebrated ordonnance of Villers-Cotterets, King François I proclaimed French the official language of the law. ${ }^{16}$ According to art. 110 of the ordonnance, all judicial acts and operations should be "done and written so clearly as to be free from ambiguity or uncertainty and any reason to ask for an interpretation."17 Accordingly, art. 111 provided that:

Since such . . . (misunderstandings) often have arisen (because of the failure) to understand the Latin words contained in these acts, we wish to have from now on all acts and all other operations ... pronounced, registered and delivered to the parties in the maternal French tongue and not otherwise. ${ }^{18}$

In practice, this prescription applied not only to Latin but also to the Italian and Spanish words contained in judicial acts. Since the "maternal French tongue" still was spoken in many ways at this date, the ordonnance did not pertain to the use of dialects. ${ }^{19}$ Later legislation, enacted during the revolutionary period when the language had stabilized sufficiently, sought to minimize the encroachment of local dialects on the national language by requiring the use of the national French language in all public acts. ${ }^{20}$

In the latter half of the 20th century, U.S. technological advances and international commercial activity set the stage for another era of French linguistic protectionism. This time the culprit was "franglais," a word coined by Professor Etiemble ${ }^{21}$ to refer to

13. See id. at 106.

14. See id. at 37, 106; Chaurand, supra n. 9 at 62 .

15. See Delaporte, "La loi relative à l'emploi de la langue française," 65 Rev. Crit.

Dr. Int. Pr. 447, 451 (1976).

16. See 2 Brunot, supra n. 9 at 30.

17. See id. (my translation).

18. See id. (my translation).

19. See Chaurand, supra n. 9 at 62 .

20. See Balibar \& Laporte, Le Français National Politique et Pratiques de la Langue Nationale sous la Révolution Française 198 (1974).

21. See Etiemble, Parlez-vous Franglais? (1964). 
the alteration of French usage occasioned by the incorporation of English terms or the literal translation of English expressions into French. Appropriation into French and misuse of such words as "leasing," "le self" and "le cameraman" are examples of the new menace to the "integrity of the French language."22

Although the uncouth integration of these terms may explain the outcry over their presence, it should be noted that foreign lexical borrowings are a normal, if not indispensable, part of the evolution and continued vitality of any language. ${ }^{23}$ For example, the French language contains numerous examples of "scholarly" words borrowed from classical languages (e.g., hebdomadaire from Greek) and is heavily indebted to Italian, which contributed quite substantially to its lexical wealth especially during the 16 th century. ${ }^{24}$ Also, the current vulnerability of French to the influence of English is not new. Throughout the 19th and early 20th centuries, in the aftermath of the industrial revolution, many English words were integrated into French through oral usage-paquebot (packet boat), bifteck (beef steak), redingote (riding coat) are notable examples and now recognized in the French lexicon. ${ }^{25}$ Finally, French vocabulary is considerably smaller than that of other modern languages. Throughout its history, French has filled its need for new terms by adding meanings to already existing words rather than formulating new ones. ${ }^{26}$ From a structural point of view then, French is particularly vulnerable to the impact of foreign terms which refer to new concepts or things.

\section{Official Efforts to Deal with Franglais}

In 1966, two years after the publication of Professor Etiemble's book, Parlez-vous franglais?, ${ }^{27}$ the French Government created a special committee, the High Committee for the Defense and Expansion of the French Language, to devise ways in which to preserve linguistic autonomy, i.e. to lessen the impact, if not to eradicate the very presence, of English language influences and borrowings. ${ }^{28}$ Its distinguished membership included well-known literary figures and linguists. ${ }^{29}$ Under the enabling legislation, the Committee was given a wide-ranging and aggressive mandate:

22. See text at $n$. 3 supra.

23. See Guiraud, Les Mots Etrangers 5-8 (1965).

24. See id. at $64-82$.

25. Id. at 83-98.

26. See generally G. \& R. Le Bidois, Syntaxe du Français Moderne (1st ed. 1935).

27. See text at $n$. 21 supra.

28. See Décret no. 66-203 of 31 Mar. 1966, J.O. of 7 Apr. 1966 at 3411, cited in Delaporte, supra n. 15 at 450 .

29. See id. 
To study the measures capable of assuring the defense and expansion of the French language;

To establish the necessary links with appropriate private organizations, namely in the area of technical and cultural cooperation;

To foster or to encourage all initiatives relating to the defense and expansion of the French language. ${ }^{30}$

The importance which the French Government attached to the committee was evident not only from the prestigious appointments that were made and the nature of its responsibilities-the French Prime Minister was to preside over the committee, which would be responsible directly to his office. ${ }^{31}$

In 1972, in accordance with the 1966 legislation and on recommendation of the Academie française, the French Government authorized the creation of commissions on terminology. ${ }^{32}$ The exact number of these commissions was to be determined ad hoc; their purpose essentially was to supplement the work of the High Committee by establishing:

For a given sector an inventory of the lacunae in the French vocabulary;

To recommend the terms necessary either to designate a new reality, or to replace undesirable foreign language borrowings. ${ }^{33}$

During the next three years, commissions were established to study French vocabulary in many areas, from public media to medicine. Upon completing their work, the commissions published lists of terms which were either mandatory or recommended replacements for English language terms in current French use. ${ }^{34}$ For example, while the term "show business" was prohibited in government-owned public media (it had been replaced by l'industrie $d u$ spectacle), the use of animateur for "disc-jockey" or exclusivite for "scoop" was simply recommended.35 Exactly which criteria the commissions used to distinguish between the two sets of terms is not readily apparent from reading the lists. Since there was no commentary, one must assume that the result strikes a balance between legislating linguistic change and encouraging it to come about through natural modification in usage. Moreover, since these lists

30. See id. (my translation).

31. See id.

32. See Decret no. $72-19$ of 7 Jan. 1972, J.O. of 9 Jan. 1972 at 4678 , cited in Delaporte, supra n. 15 at 450.

33. See id. (my translation).

34. See Delaporte, supra n. 15 at 450 n. 7.

35. See generally J.O. of 18 Jan. 1973 at 723, 728, 741, 745, 754; id. of 3 Jan. 1974 at 95 ; id. of 12 Jan. 1974 at 485 ; id. of 16 Jan. 1975 at 669. 
were applicable only to government agencies and organizations and contained few provisions relating to implementation or enforcement, their impact on the linguistic community as a whole was bound to be minimal. ${ }^{36}$

On 31 December 1975, the French Parliament enacted Law No. 75-1349 relating to the use of the French language ${ }^{37}$ in an attempt to supplement these initial efforts by waging the battle against English language neologisms on a wider front and in a more aggressive fashion.

The legislative history of the law clearly reveals that the provisions and purpose of the enacted version differ markedly from the original formulations in the draft. ${ }^{38}$ The propositions de loi generally were drafted in fairly bellicose language and were conceived as attempts to thwart the "degradation" and "contamination" of the French language. ${ }^{39}$ This combative spirit made for some rather exaggerated proscriptions. For example, according to the provisions of one proposal, French would be compulsory for trademarks and for the names of commercial companies, and technical or scientific conferences, courses and debates conducted exclusively in a foreignlanguage would be prohibited in public buildings. ${ }^{40}$ During the legislative debates, the rigid chauvinistic tone and the spirit of uncompromising linguistic purity were moderated considerably; in fact, the ostensible raison d'etre of the law was reformulated entirely and cast in language more becoming to a contemporary legislative mind. 41

The proponents of the final draft version of the law argued throughout the parliamentary debates that enactment of a law mandating the use of French in certain areas of commercial and economic activity taking place in France could be justified only in terms of consumer protection. One of the advocates of a modified version of the law explained its rationale in this way:

In the spirit of defending the public interest, the legislator must be vigilant, in regard to the presentation of products, that they are placed on the market with documentation that is intelligible to those for whom they are intended. Consumer protection is the essential and practically the sole purpose of the present text.42

36. See Delaporte, supra n. 15 at 450.

37. Loi no. 75-1349 of 31 Dec. 1975, J.O. of 4 Jan. 1976 at 189, 65 Rev. Crit. Dr. Int. Pr. 185 (1976).

38. See Premier Ministre, supra n. 3 at 9, 17, 20, 51, 54.

39. See id. at 9,17 .

40. See id.; Delaporte, supra n. 15 at 456.

41. See Premier Ministre, supra n. 3 at 5, $22 \& 23$.

42. See id. at 55 (my translation). 
The circulaire of 14 March 1977, ${ }^{43}$ in which the French Government presented its interpretation of the Law of 31 December 1975, confirmed this construction of the linguistic prescriptions in the law:

The legislator attempted to protect French users in the widest sense of that term (consumers or users of products, of goods and services, of public documents and information) against a faulty understanding occasioned by the use either of texts written exclusively in a foreign language or of French texts containing foreign terms or expressions. ${ }^{44}$

Faithful to this new, modern justification for linguistic protectionism, the provisions of the Law of 31 December 1975 in fact do require the use of French in three principal areas of consumer interest:

(1) in the marketing of goods and services destined for consumption by the French public;

(2) in offers of employment made in employment contracts to be carried out in France;

(3) in the use of public places, property or services and in contracts with public bodies or establishments. ${ }^{45}$

The law specifically excludes commercial names, trademarks and private contracts from its regulatory provisions. ${ }^{46}$ The statement of the French language prescriptions is fortified with sanctions for violations of the law. Art. 3 of the Law of 31 December 1975 provides that failure to comply with the requirements of the statute, specifically those contained in art. 1 and 5 , will be punished according to the terms of art. 13 of the Law of 1 August 1905 on suppression of the fraudulent sale of goods. ${ }^{47}$ Art. 13 provides that fines for first offenders will range from F 80 to $F 160$; for repeated violations during the same three-year period, the fine imposed could be as high as F 5,600. ${ }^{48}$ A fine can be assessed for each article offered for sale or sold in a non-conforming manner. Since the purpose of the law is to provide consumer information and protection in the presentation and sale of goods, the Service for the Repression of Fraud of the Ministry of Economy and Finance is charged with enforcement. ${ }^{49}$

43. Circulaire of 14 Mar. 1977, J.O. of 19 Mar. 1977, at 1483, 66 Rev. Crit. Dr. Int. Pr. 375 (1977).

44. See id. at 375-76 (my translation).

45. Id. at 376 (my translation).

46. Id.

47. See Loi No. $75-1349$, supra n. 37 at $185-86$.

48. See Renzis, "Commerce, Industrie, Publicité et Langue Française," 3 Les Petites Affiches, Legislation 13, 15 ( 6 Jan. 1978); 9 Bulletin Rapide de Droit des Affaires 3-4 (5 May 1977); "French Is Now Mandatory" in Commerce in France 11 (Feb.-Mar. 1977).

49. Id. 
Articles 1, 2, and 3

Art. 1 of the Law of 31 December 1975 renders the use of French compulsory in:

the description, the offer, the presentation, the written or oral advertising, the directions for use, the scope and conditions of guarantee of a good or service, as well as in invoices and receipts...

The same rules apply to all information or presentations (given or made through) radio or television programs, except when they are intended expressly for a foreign public. ${ }^{50}$

This provision adds that documentation written in French can be accompanied by several translations. ${ }^{51}$

The provisions of art. 1 in effect incorporate the work of the commissions on terminology into the statute by prohibiting the use of any foreign term or expression for which the commissions have approved a French equivalent. ${ }^{52}$ The wording of art. 1 however does not mention the distinction made in the commission reports between mandatory and recommended words and expressions; it simply refers to those terms or expressions "approved under the conditions provided for in the Decree no. 72-19 of 7 January 1972."53 Although its commentary is more explicit and detailed than the statutory language, the text of the circulaire of 14 March 1977 does not clarify the ambiguous reference to the 1972 Decree. While it interprets the statute to prohibit the use of foreign terms except in cases in which there is no French equivalent and provides an illustrative list of examples, its explanation of the role of the work of the commissions on terminology is elliptical:

When the French vocabulary presents lacunae, it can be enriched according to the procedure of the arretes taken in application of the decree no. 72-19 of 7 January 1972 concerning the enrichment of the French language. ${ }^{54}$

This literal reading of the statutory provision and of the commentary of the circulaire is not merely an academic exercise; rather it points to the problems that will arise inevitably when a court is confronted with the question of determining which foreign terms have French equivalents, an issue which incidentally has vexed and continues to confound professional linguists. For example, although the commissions have approved a certain numer of mandatory

50. See Loi no. $75-1349$, supra n. 37 at 185 (my translation).

51. Id.

52. Id.

53. Id. (my translation).

54. See Circulaire of 14 Mar. 1977, supra n. 43 at 376 (my translation). 
French equivalents, they have not, at least in their reports, indicated what standards governed their selection or what procedures were used to arrive at their results. As a consequence, a court would be obliged to devise some sort of working definition of the term "equivalent," taking into account such factors as whether a word came into French usage through a written or oral medium, whether it appears as an entry in some or all dictionaries (establishing, as a corollary, a hierarchy among dictionaries according to their quality and reputation), whether its French spelling and recommended pronunciation make it differ sufficiently from its original foreign form to give it a bona fide French tone and character, and, finally, whether its exclusive use in a technical sector may exempt it from the prohibitions of the law without impairing the consumer protection rationale.

Although not exhaustive, the foregoing list of factors to be considered by courts in applying the law points to the practical difficulty of implementing a deceptively simple and poorly drafted law and raises other more fundamental issues. The first concerns the wisdom of a legislative or judicial body applying rules requiring a linguistic community to alter its habits other than through usagethe natural process of alteration in language. Since the French Parliament was aware of the drawbacks of such an approach and decided to take action anyway, deeming English language words to constitute a sufficient menace to French consumers and to the integrity of the French language to require official action, that issue, although it still generates considerable controversy, is moot for present purposes. The second issue aligns the debate along more traditional legal grounds, namely the propriety of judicial additions to the substance of a legislative text. The ambiguity of the legislative provisions is especially pernicious in this context since the courts would exceed the bounds of their legitimate authority and would do so in an area in which judicial methodology runs counter to the usual means of initiating and ratifying linguistic change. Although the law is too recent to have given rise to a great number of cases, the uncertainty of its language undoubtedly will render implementation by the courts problematic.

The commentary of the circulaire did however elucidate the other provisions of art. 1 of the Law of 31 December 1975. For example, it did specify that the general prescription of French in all transactions involving the sale or the offering for sale of goods or services to the French public applied:

not only to the entire written form of all the documents used in the transactions (contracts, labels, catalogues, brochures, purchase and delivery orders, guarantee vouchers, instructions for use, insurance certificates, transporta- 
tion vouchers, quality certificates, etc.) but also to the wording printed on the packaging and on the merchandise itself as well as oral or written advertising. ${ }^{55}$

The circulaire reiterated that this all-encompassing legislative regulation was justified in terms of consumer protection: the French consumer should not be obliged to read and understand a foreign language in order to purchase goods or services on the French market. ${ }^{56}$

The text of the circulaire then clarified the implications for imported products. From the perspective of private international commercial transactions, this is the most significant part of the circulaire. It stipulated that if the imported products failed to conform to the linguistic prescriptions, liability would fall either upon the French importer or, if the foreign manufacturer sold his products directly on the French market, upon the foreign exporter. If the French importer delegated the task of labelling the foreign products to other retailers, he would be required to provide them with a French translation of the original label. ${ }^{57}$

The application of this regulation is unlikely to impose an overwhelming burden upon the importers and manufacturers of consumer merchandise since most of them, according to the dictates of good business sense, have affixed French language labels to products destined for export to France. ${ }^{58}$ Their advertising efforts, already conceived in terms of catering to the French public, can be modified without too much effort to satisfy the requirements of the new law. The real onus will fall upon the importers and manufacturers of highly specialized, technical merchandise (e.g. computers, machine parts, airplane components and the like). Although their clientele is limited, constituting an infinitely small segment of the French public, the literature which accompanies their merchandise is extensive and ill-suited for translation. Moreover, translations (if they are possible at all) would be astronomically expensive, timeconsuming and in fact unnecessary since users of such goods usually receive most of their professional training in English. ${ }^{59}$ The expense and inconvenience of applying the regulation in these market sectors raise serious questions about the practicality, if not the likelihood, of its enforcement. But it is precisely in this highly technical sector that the impact of "franglais" appears to be strongest and where the prescriptions of the law could be most beneficial. Application of the law to these products however would have to be justi-

\footnotetext{
55. Id. at 377 (my translation).

56. Id.

57. Id.

58. See generally, "French Is Now Mandatory," n. 48 supra.

59. Id.
} 
fied on the ground of maintaining the integrity of the French language by making it an autonomous medium of technological communication and not on the ground of protecting French consumers.

The text of the circulaire also enumerates instances in which the dealings between a foreign concern and a French commercial enterprise would be exempted from the regulation. All of these instances involve transactions which do not touch directly upon marketing goods or services on the French market:

transactions between foreign exporters and French importers;

relations between companies of the same group, some of which are established in France;

transactions relating to the export or to the re-export of goods or services intended for consumers outside the (French) national territory. ${ }^{60}$

In summary, under the literal language of the statute as interpreted by the circulaire, all documentation pertaining to a foreign product or service, including receipts, warranties, promotional and advertising material, which is offered for sale on the French market is required to be written in French. ${ }^{61}$

\section{Articles 4-7}

The provisions of art. 4 and 5 of the law relate to matters concerning French labor law; as a consequence, they are less relevant to international commercial matters conducted in France. Under these articles, any employment contract which is in writing and which is to be performed on French territory must be written in French. ${ }^{62}$ No foreign term or expression for which there is an approved French equivalent can appear in the text of these contracts. $^{63}$ In the event that a French equivalent does not exist, the contract must be accompanied by an explanation of the foreign term, written in French. ${ }^{64}$

The earlier remarks concerning the concept of equivalence between French and foreign words are pertinent to the interpretation of these provisions. ${ }^{65}$ Exactly how the concept of equivalence should be defined and how it is to be applied in a practical setting by courts and administrative agencies are unclear from the text of the statute. Also, the labor law requirements create the anomaly that an employment contract between a French employer and

60. See Circulaire of 14 Mar. 1977, supra n. 43 at 376 (my translation).

61. See "French Is Now Mandatory," supra n. 48 at 11.

62. See Loi no. 75-1349, supra n. 37 at 186.

63. Id.

64. Id.

65. See text at n. 53-55, supra. 
French employee who is to work abroad need not be written in French, but a contract between a foreign employer and foreign employee who is to work in France falls within the law. Even if the work will involve relations solely with a foreign clientele in France, the contract nonetheless must be written in French. ${ }^{66}$ An employee of foreign nationality can request that the contract be translated into his native language. While both versions have equal legal effect, should a conflict arise between the two texts, only the provisions of the foreign language text would be binding on the foreign employee. ${ }^{67}$ Moreover, all offers of employment published in newspapers or magazines must be written in French, except when there is no French equivalent, in which case the foreign term must be explained fully in French in an addendum to the advertisement, or when the publication is edited in a foreign language or the offer is aimed exclusively at foreign nationals. ${ }^{68}$

Art. 6 of the statute prescribes the use of French in all inscriptions on public buildings, places and property ${ }^{69}$ Art. 7 provides that failure to observe the strictures of art. 6 will result in loss of government funding. ${ }^{70}$ Finally, art. 8 of the statute stipulates that all contracts between a French public entity and any other person must be written in French, with the reservation that a translation of the original French version of the contract has the same legal effect as the French document. ${ }^{71}$ The circulaire adds that all the provisions of the law are in effect as of 1 February $1977 .{ }^{72}$

Analysis of arts. 4-7 of the law reveals a rather fragile coexistence between its ostensible consumer protection rationale and the desire for linguistic purity which characterized its original formulation. On the one hand, the prescriptions contained in arts. 5 and 6 relate exclusively to the use of French in the public domain where the information conveyed is intended for the French public and must be written in French to protect the consumer's right to be informed in a language intelligible to him or her. In these circumstances, one can conclude that safeguarding the integrity of the French language is but an ancillary, even haphazard, result of the primary purpose of the law. The severity of the sanction provided for in art. 7 attests the seriousness of purpose that underscores the intent to promote consumer interests.

Analysis of art. 4 and 8, on the other hand, calls for a different

66. See Delaporte, supra n. 15 at 462.

67. See Loi no. 75-1349, supra n. 37 at 186.

68. Id.

69. Id.

70. Id. at 187.

71. Id.

72. See Circulaire of 14 Mar. 1977, supra n. 43 at 378. 
statement of the fundamental intention of the statute. Neither the requirement that any written employment contract to be performed in France be written in French, nor the requirement as to contracts with French public entitites directly fosters the interests of the French consumer. Indeed, the anomalous situations to which these provisions can potentially give rise demonstrate that the proponents of the law failed to eradicate all traces of linguistic chauvinism which characterized the first propositions de loi. The practical ramifications of these provisions show that their fundamental, albeit implicit, intention was to establish the primacy of French as the language for commercial transactions taking place in France.

\section{The Belgian Decree}

On 27 June 1978, the Belgian Cultural Council of the French Cultural Community enacted a Decree On The Defense Of the French Language. ${ }^{73}$ Although it constitutes only a preliminary effort in this area, its provisions are quite comprehensive. ${ }^{74}$ Art. 1(1) of the decree requires the use of French not only in documents issued and acts taken by public administrative agencies, including the government-owned radio and television network, but also in certain commercial areas:

1. The decrees, regulations and all acts of the Cultural Council of the French Cultural Community, of the provincial and communal authorities, of the agglomerations, federations and associations of communes, and the French Commission of Culture of the agglomeration of Brussels;

2. The arretes, circulars, instructions and directives of the ministers or civil servants placed under their authority or control;

3. The correspondence, documents and productions of whatever nature coming from the agencies or offices of the State and most notably the R.T.B.F. or public interest agencies from provinces, from agglomerations ... (and the like);

4. The agreements or contracts to which the State or public interest agencies, as well as all other administrative authorities, are parties;

5. The directions for use, the guarantee, the invoices and receipts concerning a good or a service;

73. The decree bears the official publication date of 12 July 1978 and appears in Moniteur Belge 1133 (9 Sept. 1978), (information supplied by the Belgian Consulate, New York).

74. See text at n. 76-78 infra. 
6. Employment contracts and offers of employment in the press;

7. The designation, offer, presentation and the written or oral advertising of a good or a service;

8. The inscriptions affixed to the buildings, on the land or on public transportation vehicles, by persons using, for whatever reason, a good belonging to a public authority or to a distributor of a public service or an institution funded by the public authorities. ${ }^{75}$

In the hope of having the decree respected on its own merits, to encourage rather than to coerce compliance with its regulations, the Cultural Council eliminated all reference to penal sanctions and fines from the text of the decree. ${ }^{76}$ The only enforcement provision which remains in the enacted version is worded in conditional language and applies only to educational institutions. Art. 5 of the decree reads:

Without harming research or educational interests, funding of any nature granted by the ministers of the French Culture and National Education or by the French Commission of Culture of the agglomeration of Brussels, can be subordinated to the respect of the present decree.

Any serious failure (to respect the provisions of the present decree) can entail, after the giving of notice, the refusal to renew the said grants. ${ }^{77}$

In this regard, art. 4 provides that the minister responsible for French culture and the Minister of Education shall give the necessary directives to have the substance of the decree made known to the relevant administrative and public interest agencies. ${ }^{78}$

In addition to fostering rather than mandating linguistic change, the Belgian decree contains other features which make it a more acceptable instrument of linguistic reform than the French law. First, its purpose, to defend the French language, is stated clearly in its title and substantive provisions. The proponents of the decree did not see the need to dress their legislation in garb that disguised its essential purpose. According to them, the decree reflects an effort to

... put an end to a practice which resulted in the pure and simple substitution of English for French . . .

[T]o preserve (the French language) ... against the tion).

75. Decret sur la Defense de la Langue Française, supra n. 73, art. 1 (my transla-

76. See Spaak et al., supra n. 2 at 3.

77. See Decret, supra n. 75 , art. 5 (my translation).

78. Id., art. 4. 
obscurity which results from inconsiderate borrowings from foreign (language) vocabularies . . .

The authors of this proposal therefore wish to see consacrated two principles, which appear to them to be complementary.

On the one hand, to proscribe "franglais" and more generally to banish foreign borrowings each time it is not a question of designating products or ideas which characterize very specially a country or a region.

On the other hand, to put an end to the "foreign unilingualism" which is beginning to be widespread, even in the acts and documents of the public authorities. ${ }^{79}$

Although the provisions of the decree are intended to support the public interest and imply a consumer protection rationale, there is no mistaking their fundamental purpose.

Second, in discussing the requirements relating to equivalence between French and foreign words, the text of the decree makes an explicit distinction between mandatory and recommended terms. ${ }^{80}$ It sets out clearly that the language prohibitions it contains are based upon the two-part lists of terms established by the International Council on the French Language. ${ }^{81}$ French equivalents for foreign terms will be either mandatory or simply recommended depending upon the classification attributed to them in these lists. Despite this clarification, which is lacking in the French law, since these two-part lists are in the main enumerations, the lack of explicit criteria for determining equivalency and questions as to the suitability of judicial interpretation and application will remain if these provisions ever give rise to litigation. ${ }^{82}$

In the last analysis however, the Belgian Cultural Council appears not only to have stated the problem more forthrightly than the French Parliament, but also to have shown greater sensitivity and common sense in approaching the complex problem of revamping language habits. The latter is evident especially in that the decree is designed as a preliminary measure, a sort of pilot program, and in that it makes compliance a moral as opposed to legal obligation by not providing sanctions for failure to comply. This incremental and experimental approach is preferable in light of the circumstances normally associated with the evolution and development of language.

\footnotetext{
79. See Spaak et al., supra n. 2 at 1-2 (my translation).

80. See Déret, supra n. 75 at art. 1 (2) (3).

81. Id.

82. See text at $\mathbf{n}$. 53-55 supra.
} 


\section{French Case Law}

The decisional law dealing with the French legislation consists of nearly half-a-dozen cases brought by a French consumer protection group and a fairly sizeable number of cases brought by the agency of the Ministry of Finance authorized to prosecute violations of the law. ${ }^{83}$ The suits brought or joined by the consumer group (AFGULF, the Association Française Génerale De L'Utilisation De La Langue Française) have been more conspicuous; the consumer protection litigation has undergone a two-fold evolution, gaining its strongest momentum in recent months.

In 1978, under its former leadership, AFGULF brought an action before the Tribunal de police of Paris, a court of first instance, against British Airways, alleging that BA had been selling airline tickets written exclusively in English, for its Paris-London run, in France to French passengers in violation of art. 1 of the Law of 31 December 1975.84 The Paris court agreed that BA had violated the law, imposing upon it a fine of $\mathrm{F} 80$ for each non-conforming ticket sold and awarding AFGULF F 200 in compensation (dommages et interets). BA subsequently lodged an appeal, but discontinued the action, presumably reasoning that the amount of the fine did not warrant the expense of further litigation. BA is currently selling its tickets in France with a French language insertion explaining the terms and conditions of its passenger contract.

The significance of the British Airways case does not lie in the sanction imposed-it is quite evident that the judgment, from the perspective of assessing the fine, was a jugement de principe. Rather, this case was important because the court recognized that in cases involving the linguistic legislation, the consumer interest association had standing to bring an action (ester en justice) as a partie civile - a ruling of substantial moment for AFGULF.

After British Airways, AFGULF brought a similar action against Air Malta. An initial hearing took place on 10 June 1980; owing to financial difficulties and a concomitant morale problem however, the consumer protection association discontinued the litigation. AFGULF remained inactive in this area until the end of 1980 when its leadership was revamped.

Under new leadership, AFGULF regained its initial vitality, filing some five actions, most of which are still pending. The Bon Marché case, involving a well-known Parisian department store, was the subject of a recent decision. There AFGULF joined an action brought by an elderly woman who had been injured when a pres-

83. Information concerning current status of case law obtained from $M$. Fichet, secretary of AFGULF, in an interview of 28 April 1981.

84. Le Monde, 23 Mar. 1978 at 36. 
surized bottle purchased at the department store exploded in her hands. The directions for use were exclusively in English. In March 1981, a Paris court held that AFGULF had gagne de cause, imposing a fine of F 400 upon BM and awarding the consumer group F 200 in compensation. The Bon Marché decision consolidated the previous advances that had been made in British Airways, recognizing that AFGULF had standing to bring or join consumer actions as a partie civile.

A number of suits remain outstanding and the decisions reached in these cases probably will determine the effectiveness of the linguistic legislation and the role of consumer groups in enforcing the law. AFGULF has brought an action against SEITA, a French company which has a monopoly over the distribution of tobacco and matches in France. According to the representatives of the consumer group, SEITA, in an effort to make inroads into the foreign cigarette market in France, began selling a rival mild cigarette called "News." In order to emphasize the similarity of its product to American and English competitors, SEITA had most of its advertising for the product done in English. A preliminary decision in this case is expected at the beginning of June 1981; the litigation eventually may be transferred to a Tribunal correctionnel which has the authority to assess a larger fine for violations of the law.

Two other actions are pending; both involve the sale of toys having potential dangers for young children but which are not accompanied by French language warnings. The first case was brought against Pier-Imports which sold christmas tree decorations-known as "Pepperman-Pier" - in the form of candy. The decorations, which were not edible, presented an evident risk to young children, but the instructions for use were exclusively in English. The Tribunal de police in Long-Jumeau (Vosges) is expected to render a ruling in this case in May 1981. Second, AFGULF also has brought an action against the French importer of a space galaxy toy which is potentially dangerous and fails to contain any warning in French.

Finally, AFGULF has filed suits against TWA and PAN-AM for alleged violations of the 1975 Law. These cases involve some rather delicate legal questions which are critical to the future enforcement of the linguistic legislation. In an apparent attempt to comply with the law, the two airline companies printed small French language notices explaining the terms and conditions of their passenger contracts. These notices then were distributed to travel agencies which were given the responsibility of passing them on to the purchasers of tickets. The legal questions which arise are: (1) have the airline companies demonstrated a good faith effort to comply with the linguistic prescriptions, and (2), in the event of litigation, is a suit 
properly brought against the airline company or the travel agency or both? These cases currently are in continuance.

AFGULF officials are enthusiastic and promise more litigation in the future-either actions brought directly by AFGULF or ones filed by private individuals that it joins. Despite the public lead taken by the consumer protection group, the Service de la repression des fraudes of the Ministry of Finance, which is authorized to enforce the 1975 Law, has not been inactive in this area (although it has acted with undeniable discretion). The Ministry of Justice has not compiled statistics for the number of legal actions brought throughout France involving the $1975 \mathrm{Law}$, but it did provide a statistical breakdown of the linguistic litigation which took place in Paris between 1977-1979. During this three-year period, some seventy judgments were rendered involving the 1975 Law (19 in 1977; 13 in $1978 ; 38$ in 1979). To my knowledge, few if any of these court decisions have appeared in print and the Ministry of Justice study did not reveal their outcomes.

\section{Conclusions}

Clearly, there is a revival of interest in the linguistic legislation in the principal consumer group and official government action has been steadfast, albeit quite inconspicuous for whatever reason. The policy choice between linguisitc purity and consumer protection, on the one hand, and the safeguarding and fostering of commercial interests on the other hand, may not be as easy to resolve as it appears at first blush.

The British Airways case-important on standing-was not an especially propitious starting point since its facts pointed to a flagrant violation of the statutory provision. The TWA and Pan Am cases raise more intricate issues. Subsequent cases, depending upon the extent to which the law is taken seriously and enforced rigorously, might be even more complex. Indeed, one wonders whether such a law can be enforced at all, ${ }^{85}$ except in circumstances amounting to deliberate and egregious disregard of its substance or where a tort action is brought for injury resulting from the inability to understand foreign language literature accompanying a product. Should the law be zealously enforced, the burden of supplementing the vague provisions of the statute with a measure of legal precision, of articulating a coherent statement of purpose in a context of dualistic intent, and of reconciling the statute with commercial expediency where application of its literal language would give rise to an

85. See Delaporte, supra n. 15 at 474-76. 
anomalous result, will fall upon the courts-systemic and practical objections notwithstanding.

Application of the law also will have EEC repercussions. The compatability of the law with Common Market principles has already been questioned in the EEC Commission. ${ }^{86}$ While noting that the provisions of the law, in certain cases, could hinder "intracommunity exchanges," it nonetheless ruled, upon the information provided by the French authorities, that:

the law did not apply to the documents and materials intended solely for professional circles; ${ }^{87}$

(T) he objective of the law being the informing and the protecting of consumers, the Commission will endeavor to examine, in the variety of cases and the categories of cases involving application of the law, whether and in what measure the eventual impediments are justified by this objective, without constituting a means of arbitrary discrimination or a disguised restriction on trade among the member states. ${ }^{88}$

The consumer protection rationale of the new linguistic legislation can be seen as a product of contemporary legislative preoccupations with quality-of-life issues. As such, the statutory prescriptions can be reconciled with the principle of free trade among EEC member states and to the exigencies of international commerce since they require only that foreign exporters provide their French clients with intelligible information. The other, less conspicuous, objective of the law, preserving the lexical and syntactical integrity of the French language, is also satisfied by this rationale. As analysis of the law has revealed however, certain of its provisions tend to expand the scope of the latter objective, in effect giving it primacy over the stated intention of the law. It appears that rigorous literal application of the statutory provisions in certain cases would place French on an equal footing with English as the language of international commerce-at least within France. Although such an attempt may be laudable, it would wreak considerable havoc in the normal operation of international commerce transactions. It is hoped that the law will be applied with a good deal of common sense and with due regard to the undeniable realities of international business life. However ominous "franglais" may be to the French language, it is well to remember that foreign borrowings are part of the normal process of language evolution, that English language influence, although substantial, is limited primarily to the commercial sector, and that the apparent weakness of the French language in this area

86. EEC J.O. of 10 Nov. 1977 (no. C. 270/1), Written Question no. 349/76.

87. Id. (my translation).

88. Id. (my translation). 
does not compromise its vitality in the literary and artistic fields. There is a clear need to define the scope of the law's application, limiting its regulatory impact to matters directly relevant to consumer protection and striking a balance between the desire to maintain the purity of the language and the natural processes of linguistic evolution. 